\title{
TRANSLATION OF ENGLISH-VIETNAMESE FILM SUBTITLES IN SOME POPULAR MOVIES
}

Duong Hong Yen*, Vu Thi Quyen

$T N U$ - School of Foreign Languages

\section{ABSTRACT}

In accordance with the great need of studying English in Vietnam, especially through English movies, translating subtitles has become a decent job as well as demanding work. With the aims of figuring out which strategies have been used in translating English-Vietnamese film subtitles and providing some implications on subtitle translation, this article looks at those of five popular movies on the website www.studyphim.vn to analyze namely "Ice Age: The Meltdown", "Friends", "Prison Break", "Avengers: Age of Ultron", and "The Hobbit: An Unexpected Journey". The researcher watched and compared English and Vietnamese subtitles of the movies to find out the procedures and strategies of translation employed based on the theoretical framework adapted from Newmark's and Baker's theories about translation. After analyzing, there were principal procedures and strategies have been used as follows: literal translation, transference, naturalization, through translation, shift or transposition, notes, translation by a more neutral/less expensive word, translation by cultural substitution, translation by paraphrase using a related word or using unrelated words, translation by omission, collocations, and idioms. The study also found out errors that are still existed in the subtitle translation of the collected films and they should be corrected. This project is hoped to contribute to the literature for future research on similar topic.

Key words: translation; English movies; English - Vietnamese film subtitles; translation procedures; translation strategies.

Received: 25/02/2020; Revised: 20/3/2020; Published: 23/3/2020

\section{DỊCH PHỤ ĐỀ PHIM ANH-VIỆT TRONG MỘT SỐ BỘ PHIM PHỔ BIẾN}

\section{Dương Hồng Yến*, Vũ Thị Quyên} Khoa Ngoại ngũu - ĐH Thái Nguyên

\section{TÓM TẮT}

Với nhu cầu học tiếng Anh ngày càng cao ở Việt Nam, đặc biệt là thông qua các bộ phim tiếng Anh, dịch phụ đề phim đã trở thành một công việc tốt nhưng cũng đòi hỏi khắt khe. Với mục đích nghiên cứu các chiến lược dịch thuật đã được sử dụng để dịch phụ đề phim Anh-Việt và đưa ra một số gợi ý cho dịch phụ đề phim, bài báo này tập trung khai thác năm bộ phim phổ biến trên trang web www.studyphim.vn để phân tích: "Kỷ Băng hà: Băng tan", "Những người bạn", "Vượt ngục", "Biệt đội siêu anh hùng: Đế chế Ultron", và "Người Hobbit: Hành trình vô định". Tác giả đã xem và so sánh phụ đề tiếng Anh và tiếng Việt của những bộ phim này để tìm hiểu về quy trình và chiến lược dịch được sử dụng, dựa trên khung lý thuyết được điều chỉnh từ các lý thuyết về dịch thuât của Newmark và Baker. Kết quả phân tích cho thấy các quy trình và chiến lược dịch thuật chủ yếu đã được sử dụng như sau: dịch nguyên văn, dịch dựa trên phiên âm, dịch nghĩa tự nhiên, sao phỏng, dịch đổi chức năng ngữ pháp, ghi chú, dịch sử dụng từ ngữ trung lập hơn, dịch bằng cách diễn giải một từ liên quan hoặc nhiều từ không liên quan, dịch dựa trên khác biệt văn hóa, dịch lược bỏ, sử dụng ngữ cố định và thành ngữ. Bên cạnh đó, nghiên cứu cũng cho thấy bản dịch phụ đề của các bộ phim được thu thập vẫn còn khá nhiều lỗi và cần được chỉnh sửa. Tác giả hi vọng nghiên cứu này sẽ góp phần làm phong phú cở lý luận cho các nghiên cứu tiếp theo về dịch phụ đề phim.

Từ khóa: dịch thuật; phim tiếng Anh; phu đề phim Anh - Việt; quy trình dịch thuật; chiến luợc dịch thuật.

Ngày nhận bài: 25/02/2020; Ngày hoàn thiện: 20/3/2020; Ngày đăng: 23/3/2020

* Corresponding author. Email: yendh@tnu.edu.vn

DOI: https://doi.org/10.34238/tnu-jst.2020.03.2724 


\section{Introduction}

It is widely recognized that translating from one language into another has never been an easy job even for the most experienced translators. Translation, involving the transposition of thoughts expressed in one language by one social group into the appropriate expression of another group, entails a process of de-coding, re-coding and en-coding. It is believed to "render the meaning of a text into another language in the way that the author intended the text" [1]. Since studying English by watching films in English language has become much more common among learners in the world, especially in Vietnam, the translation of subtitles is raised as a matter of concern for researchers. Nevertheless, not many studies on the issue of the translation of English Vietnamese film subtitles have been found so far. Some notable research works that should be mentioned are those by Nhung [2] and $\mathrm{Ha}$ [3]. Nhung [2] has successfully exploited the equivalence of English - Vietnamese translation for subtitles at word level of some documentary films. The later study [3] has brought some interesting insights into film subtitle translation; however, the website the researcher used for analysis is currently corrupted. The website www.studyphim.vn is one of the leading sites in film translation with both English and Vietnamese translation subtitle with a large number of viewers. Interestingly, the audience can also look up any English words they want while watching the movies at the same time. Those reasons may explain how this study came into being. This article is expected to enhance the literature of research on subtitle translation and serve as a helpful reference for individuals who are pratising EnglishVietnamese translation and in the thirst of mastering English language.

The study aimed to: 1) investigate which procedures and strategies adopted in translating subtitles in the five selected films; 2) give some suggestions for improving visible errors in subtitling if any.

\section{Methodology}

\subsection{Data source}

This article focuses on the translation of English into Vietnamese subtitle of five films "Ice Age: The Meltdown" [4], "Friends" [5], "Prison Break" [6], "Avengers" [7], and "The Hobbit" [8] on the website www.studyphim.vn. The reason why these movies were selected is that they are popular among audiences in the world in general and in Vietnam in particular. Moreover, the films belong to different genres, varied from cartoon, sitcom, thriller, science fiction to adventure which could reach the audience at different ages.

\subsection{Data analysis method}

There have been a variety of translation procedures and strategies prosed by different linguists and researchers [9]. In this article, the English and Vietnamese subtitles of the collected movies were analyzed based on the theoretical framework adapted from Newmark's and Baker's theories about translation procedures and translation strategies and then they were compared to find out the procedures and strategies that translators used to render the films.

\subsubsection{Translation procedures}

The followings are some basic translation procedures that Newmark [10] presents:

\section{Literal translation}

Literal translation is the process in which the grammatical constructions of source language (SL) are converted to their nearest target language (TL) equivalents, but the lexical words are again translated singly, out of context.

\section{Transference}

This is the case of transferring an SL word to a TL text. It includes transliteration and is the same as what Harvey [11] named "transcription".

\section{Naturalization}

Naturalization translation process adapts the SL word first to the normal pronunciation, then to the normal morphology of the TL. 


\section{Cultural equivalent}

It means replacing a cultural word in the SL with a TL one but they are not accurate [10].

\section{Functional equivalent}

This translation process requires the use of a culture-neutral word.

\section{Descriptive equivalent}

In this procedure, the meaning of the culturebound term (CBT) is explained in several words.

\section{Componential analysis}

It means "comparing an SL word with a TL word which has a similar meaning but is not an obvious one-to-one equivalent, by demonstrating first their common and then their differing sense components" [10].

\section{Synonymy}

Synonymy refers to a "near TL equivalent" [10].

\section{Through-translation}

It is the literal translation of common collocations, names of organizations and components of compounds. It can also be called calque or loan translation.

\section{Shifts or transpositions}

It involves a change in the grammar from SL to TL, for example, (i) a change from singular to plural, (ii) a change required when a specific SL structure does not exist in the TL, (iii) a change of an SL verb to a TL word, a change of an SL noun group to a TL noun, etc.

\section{Modulation}

It occurs when the translator reproduces a message of the original text in the TL text in conformity with the current norms of the TL, since the SL and the TL may appear dissimilar in terms of perspective.

\section{Recognized translation}

It occurs when the translator "normally uses the official or the generally accepted translation of any institutional term" [10].

\section{Compensation}

It means the loss of meaning in one part of a sentence is compensated in another part.

\section{Paraphrase}

In this procedure, the meaning of the CBT is explained. Here the explanation is much more detailed than that of descriptive equivalent.

\section{Couplets}

It occurs when the translator combines two different translation procedures.

\section{Notes}

Notes are additional information in a translation.

\subsubsection{Translation strategies}

Different scholars have various perspectives to the aspects of the act of translation so they define and describe different types of strategies. It was mentioned that Baker [12] lists the most applicable set of strategies which have been used by professional translators to cope with the problematic issues while doing a translation task.

\section{Equivalence at word level}

\section{Translation by a more general word}

This is one of the most common strategies to deal with many types of nonequivalence. As Baker believes, it works appropriately in most, if not all, languages, because in the semantic field, meaning is not language dependent.

Translation by a more neutral/ less expressive word

This is another strategy in the semantic field of structure. A translator may use a more neutral or less expressive word to avoid the author's personal feelings that may reflect on the text.

\section{Translation by cultural substitution}

This strategy involves replacing a culturespecific item or expression with a target language item considering its impact on the target reader.

Translation using a loan word or loan word plus explanation

This strategy is usually used in dealing with culture-specific items, modern concepts, and 
buzzwords. Using the loan word with an explanation is very useful when a word is repeated several times in the text. At the first time, the word is mentioned by the explanation and in the next times the word can be used by its own.

Translation by paraphrase using a related word

This strategy is used when the source item in lexicalized in the target language but in a different form, and when the frequency with which a certain form is used in the source text is obviously higher than it would be natural in the target language.

Translation by paraphrase using unrelated words

The paraphrase strategy can be used when the concept in the source item is not lexicalized in the target language.

When the meaning of the source item is complex in the target language, the paraphrase strategy may be used instead of using related words; it may be based on modifying a super-ordinate or simply on making clear the meaning of the source item.

\section{Translation by omission}

This may be a drastic kind of strategy, but in fact, it may be even useful to omit translating a word or expression in some contexts. If the meaning conveyed by a particular item or expression is not necessary to mention in the understanding of the translation, translators use this strategy to avoid lengthy explanations.

\section{Translation by illustration}

This strategy can be useful when the target equivalent item does not cover some aspects of the source item and the equivalent item refers to a physical entity which can be illustrated, particularly in order to avoid over-explanation and to be concise and to the point.

\section{Equivalence above word level:}

Equivalence above word level involves in dealing with the differences in collocations and idioms of the SL and the TL.

\section{Findings and discussions}

\subsection{Procedures used in translating subtitles} of the selected films

\subsubsection{Literal translation}

Since the language in the movies is spoken language used in daily life, literal translation is proved to be the outstanding procedure.

For instance:

- You're telling me about your mom? What's the matter with you?

= Cậu đang kể với tớ về mẹ cậu? Cậu bị sao thế? (Friends, season 3, episode 1)

- Well, I'm pleased to find you remember something about me even if it's only my fireworks.

= Ta thấy vui vì cậu có chút ấn tượng về ta dù chỉ về mớ pháo bông pháo hoa ấy.

(The Hobbit: An Unexpected Journey)

\subsubsection{Transference}

In some cases, the subtitlers use transcription of the SL words. This procedure not only makes their translation job simple but also keeps original meanings.

For instance:

- This glycoside saxitoxin hybrid goes to work in the blood stream instantly.

= Hợp chất glycoside saxitoxin này sẽ ngấm vào máu ngay lập tức. (Prison Break, season 1)

- NATO's got him.

= NATO đã bắt hắn rồi. (Avengers: Age of Ultron)

\subsubsection{Naturalization}

This procedure is commonly used for subtitling text referring distances in the selected movies.

For example:

- On foot? Maybe two miles.

= Đi bộ hả? Khoảng 2 dặm. (Prison Break, season 1) 
- He swung his club so hard, it knocked the Goblin king's head clean off and it sailed $\mathbf{1 0 0}$ yards through the air and went down a rabbit hole.

= Ông ấy đã nện những búa oanh liệt, đánh bay đầu vua bọn Gia tinh bay xa tận cả trăm thước rồi rơi vào hang thỏ. (The Hobbit: An Unexpected Journey)

- Trail went cold about 100 miles out, but it's headed north.

= Mất dấu trong 100 dặm, tôi nghĩ nó đã bay lên phía bắc (Avengers: Age of Ultron)

\subsubsection{Through translation}

- Salvage Yard African Coast = Khu tàu đắm bờ biển Châu Phi (Avengers: Age of Ultron)

\subsubsection{Shift or Transposition}

- Not much of a life for them.

= Cuộc sống ở đó không hợp với họ đâu. (Prison Break, season 1)

\subsubsection{Notes}

In the movies Avengers, in one of Banner and Natasha's conversations, it is really helpful when the translator uses notes in the subtitle so that viewers could get more information about the location mentioned at that time.

For instance:

In the Red Room where I was trained,...

$=$ Trong căn phòng đỏ (Xô Viết), nơi mà em được huấn luyện,... (Avengers: Age of Ultron)

3.2. Strategies used by the translators of the website

3.2.1. Equivalence at word level

* Translation by a more neutral/ less expensive word

- Give him hell.

= Cho hắn biết mùi đi. (Avengers: Age of Ultron)

* Translation by cultural substitution

This process could be found in a lot of movies. According to Baker [8], this translation strategy makes the translated text more natural, more understandable and more familiar to the target reader.

- It was just a figure of speech. = Chỉ là phóng đại chút thôi. (Ice Age: The Meltdown)

- He sees me in a two-piece for the first time. Lần đầu tiên anh ấy nhìn thấy tớ mặc bikini. (Friends, season 5, episode 1)

- Come on, bugger face. = Đi thôi, mặt lọnn. (Friends, season 5, episode 1)

- Will be dragging around $\mathbf{1 7 0}$ pounds of dead Alabama flesh with him.

= Còn thằng nhóc này sẽ phải kéo lê một đống thịt $\mathbf{7 7}$ ký. (Prison Break, season 1)

- We're standing 300 feet below it.

= Chúng ta cách hố chỉ chura tới $\mathbf{1 0 0}$ mét. (Avengers: Age of Ultron)

* Translation by paraphrase using a related word

- He was talking about finding something new, a game-changer.

= Hắn nói mình đang tìm một thứ mới, một thứ thay đổi cuộc chơi. (Avengers: Age of Ultron)

* Translation by paraphrase using unrelated words

- I'm in a loop!

= Tôi lại rơi vào hoàn cảnh đó rồi.

(Avengers: Age of Ultron)

* Translation by omission

- Cool! Oh, it looks like a tiny little person drowning in your cereal.

= Hay thật! Nhìn như có người đang chết đuối trong bát ngũ cốc của cậu vậy. (Friends, season 3, episode 1)

3.2.2. Equivalence above word level

* Collocations

- I'll keep in touch.

= Ta sẽ liên lạc thường xuyên. (Ice Age: The Meltdown) 
- This is a ruse and a filthy lie.

* Idioms

- Cry me a river, blubber-tooth tiger. Have some fun.

= Càu nhàu gì thế, anh bạn răng dài. Vui vẻ lên. (Ice Age: The Meltdown)

- Sir, it's none of my business, but are you gonna call the Governor?

= Giám đốc, tôi biết không phải việc của tôi, nhưng mà ông có định gọi cho ngài thống đốc không? (Prison Break, season 1).

\subsection{Visible errors of translation in collected subtitles}

While studying the movies and their subtitles, the researcher found that there are some problems in subtitling. Take an idiomatic expression in the film "Ice Age: The Meltdown" as an example:

- Hey, buddy, have you seen a mammoth?

= Này anh bạn, có thấy con ma-mút nào không?

- I sure have. Big as life.

= Có. To và sống động.

- Where?

= Ở đâu?

- I'm looking at him.

= Trước mặt tôi đây. (Ice Age: The Meltdown)

As can be consulted in a lot of dictionaries, this idiom should mean "a colorful way of saying that a person or a thing appeared, often surprisingly or dramatically, in a particular place". However, the subtitler seems to translate the meaning literally from English to Vietnamese. Thus, the excerpt is suggested to be translated as follow:

=> Suggested version:

- Này anh bạn, anh có thấy con ma-mút nào không?

- Đương nhiên là có. Thấy rõ ấy chứ.

- Ở đâu?

- Trước mặt tôi đây.
Errors also appeared in the subtitles of other movies:

\section{The Hobbit: An Unexpected Journey}

- It is the start of the Dwarves' new year, when the last moon of autumn and the first sun of winter appear in the sky together.

= Đó là ngày đầu năm mới của người lùn, là ngày đầu tiên của tuần trăng cuối Thu, ngay trước ngưỡng cửa Mùa Đông.

=> Suggested version: Đó là thời điểm đầu năm mới của Người lùn - khi mặt trăng cuối thu và mặt trời đầu đông cùng xuất hiện trên bầu trời.

Friends, season 5, episode 2

- He was a cab driver we had in London.

= Anh ta là tài xế taxi của bọn tớ ở London.

=> Suggested version: Anh ta là tài xế taxi của bọn tớ hồi còn ở Luân Đôn.

Friends, season 3, episode 10

- And what is second prize?

$=$ Và còn giải hai thì sao?

- A 10-speed bike.

= Một chiếc xe đạp.

=> Suggested version:

- Thế còn giải nhì thì sao?

- Một chiếc xe đạp.

\section{Conclusion}

In summary, the article is a quick glance at the subtitles of the five prominent films on the website www.studyphim.vn in the perspectives of Newmark and Baker's theory about translation procedures and strategies.

After analyzing the film subtitles, the author can conclude that the most common procedure used in translating those films falls to literal translation while translation strategies are varied. It is hardly denied that subtitling is a demanding job; therefore, problems of non-equivalence which could be resulted from either the subtitlers' misunderstanding of the context or their lack of linguistic competence are still seen. 
There exist several crucial implications for the findings of the present study, which could be fallen in two groups: theoretical implication and pedagogical implications. In terms of theoretical implication, when translating film subtitles, translators should consider to apply various translation strategies, especially those proposed by Baker. Film genre is also an important factor to discover the meanings of language used. With regard to pedagogical implications, those who attend translation courses should be well aware of translation procedures and strategies.

\section{REFERENCES}

[1]. P. A Newmark, A Textbook of Translation. Shanghai: Shanghai Foreign Language Education Press, 2001.

[2]. L. T. Nhung, "Equivalence of EnglishVietnamese translation for subtitles of some documentary films," M.A thesis, Vietnam National University, Vietnam, 2011.

[3]. N. T. T. Ha, "A study of translation of EnglishVietnamese subtitles in selected English films from the website Kst.net.vn," M. A thesis, Vietnam National University, Vietnam, 2012.

[4]. "Ice Age: The Meltdown". [Online]. Available: https://www.studyphim.vn/movies/ ice-age-2-the-meltdown. [Accessed Dec. 20, 2019].

[5]. "Friends". [Online]. Available: https://www. studyphim.vn/movies/friends-season-3 \& https://www.studyphim.vn/movies/friendsseason-5. [Accessed Dec. 27, 2019].

[6]. "Prison Break". [Online]. Available: https://www.studyphim.vn/movies/prisonbreak-season-1. [Accessed Jan. 10, 2020].

[7]. "Avengers: Age of Ultron". [Online]. Available: https://www.studyphim.vn/movies/ avengers-age-of-ultron. [Accessed Jan. 16, 2019].

[8]. "The Hobbit: An Unexpected Journey". [Online]. Available: https://www.studyphim. vn/movies/the-hobbit-an-unexpected-journey. [Accessed Feb. 5, 2020].

[9]. M. Ordudari, "Translation procedures, strategies and methods," Translation Journal, vol.11, no. 3, July, 2007. [Online]. Available: http://translationjournal.net/journal/41culture. htm. [Accessed Nov. 11, 2019].

[10]. P. Newmark, Approaches to Translation. Prentice Hall International (UK) Ltd, 1988.

[11]. M. Harvey, A beginner's course in legal translation: the case of culture bound terms. ASTTI/ETI, 2000, pp. 357-369.

[12]. M. Baker, In Other Words. A Coursebook on Translation. Routledge - London and New York, 1992. 